\title{
Digital transformation in nursing education as perceived by students of COVID-19
}

\author{
Sanaa Saber Mohamed ${ }^{1}$, Ragaa Dahi Mohamed ${ }^{2}$, Safaa Abdelaziz Rashed $^{3}$ \&Om Hashem Gomaa Ragab ${ }^{4}$ \\ ${ }^{1 .}$ Lecturer of Critical Care \& Emergency Nursing, Faculty of Nursing, Sohag University, Egypt. \\ 2. Lecturer of Critical Care \& Emergency Nursing, Faculty of Nursing, South Valley University, Qena, Egypt. \\ ${ }^{3 .}$ Lecturer of Nursing Administration, Faculty of Nursing, Sohag University, Egypt. \\ ${ }^{4 .}$ Lecturer of Nursing Administration, Faculty of Nursing, Sohag University, Egypt.
}

\begin{abstract}
Emergent of Corona virus at 2019 (COVID-19) has created a significant challenge for global higher education, where most countries had to transform to digital learning in short period of time. This study aims to assess the digital transformation in nursing education as perceived by students of COVID-19. Design: A descriptive correlational research design was utilized. Setting: Faculties of nursing in both South Valley and Sohag Universities. Sample: A convenient sample of students had been chosen using OpenEpi Version 3 software. Tool An interviewing questioner covers three parts: part 1, Personal data, and part 2: assessment of digital transformation during COVID-19, and part 3: the ability to compliance with digital transformation. Results: Less than two thirds of study sample were satisfied by the experience of distance learning during COVID-19 pandemic and perceived that faculties of nursing are able to be digitally transformed. Conclusion: There is a highly statistical significant difference regarding learning experience during the pandemic in relation to digital transformation ability, so faculties of nursing has to analyze its situation abilities, resources and facilities needed for digital transformation. Recommendations: Equip the higher education institutions with essential infrastructure, technical support, faculty members and students training, and providing tablets for higher education students that helps to overcome such Covid-19 pandemic.
\end{abstract}

\section{Keywords: Digital transformation, COVID -19, Pandemic \& Nursing education.}

\section{Introduction}

Coronavirus (COVID-19) pandemic has had such an extensive impact on the global higher education sector (Perrotta, 2020). Digital approach had embraced by educational institutions to instruction and student learning, dramatically transitioning from face to face classroom instruction to predominantly distance learning where teaching is provided remotely on digital platforms (Armstrong-Mensah, et al., 2020). Now a lot of schools, colleges across the world are moving towards digital transformation. Continuing education can be provided without getting much affected during the quarantine period (Kwary \& Fauzie, 2018).

Several creative solutions that use technology to enhance the experience of virtual learning for students in higher education have been proposed, including the flipped classroom model, teleconferencing, and procedural simulation (Chick, et al., 2020). Online platforms such as Zoom, Blackboard, Canvas, Google Meet, and Microsoft Teams have been developed (Jowsey, et al., 2020). These changes, along with other measures taken to contain the pandemic, have affected the well-being, lifestyle, and functioning of students engaged in higher education (Zamira \& Linda, 2020). Nursing care is very specific so verbal interpretations and conversations must be combined with digitally supported education (Billings, 2018). Digital transformation is a process that aims to improve an entity by triggering significant changes to its properties through combinations of information, computing, communication, and connectivity technologies" (Vial, 2019).

The significance and effectiveness of implementing elearning through digital transformation are its ease of use, flexibility and better control over the environment (Kwary \& Fauzie, 2018). However, despite its advantages there are quite a few significant barriers in digital transformation we summarize as existing resources and capabilities, including factors such as technology, culture, practices, people's skills and competences as well as their values, attitudes, identities and mindsets (Vial, 2019).

Faculties and students need to understand and be able to utilize digital technologies in everyday life in meaningful ways (Song, et al., 2020). Universities and other similar institutions are expected to be concerned with developing and implementing technological communication infrastructures that will provide them with appropriate channels to communicate with their audiences. In addition, these communication technologies should provide students and teachers with the tools they need to facilitate their interaction so that the teaching and learning mission can be achieved (Comi, et al., 2017). 
Considering the relatively recent advent of this teaching method in Egypt, both teachers and students are still in the process of be familiar with the new methods. At this point of time, it is important to find out the views and perspectives of students regarding this virtual approach to teaching and learning. If the students are attuned to the new methodology, would prefer any modifications; or rather want to go back to traditional learning altogether (Abbasi, et al., 2020). Therefore, the aim of this study was to assess the perceptions of students towards digital transformation in nursing education in the light of COVID-19.

\section{Significance of the study}

Digital transformation refers to changes that digital technologies cause and that influence various aspects of human life. Authors' mainly focused on the impact of the digital transformation in the context of commercial organizations and business processes. Digital transformation is one of Egypt 2030 goals that help in raising Egypt international score. In this study, researchers aim to examine how digital transformation affects nursing students on higher education. One of challenges facing higher education nowadays is corona virus (COVID-19) crises that necessitate the use of digital transformation and Elearning to overcome this pandemic, which consider a disaster and emergency situation facing education in general and specifically higher education.

\section{Aim of the study}

This study aimed to assess the digital transformation in nursing education as perceived by students of COVID-19.

\section{Research questions}

- Does nursing students have had a satisfactory experience of digital transformation in learning during COVID-19 pandemic?

- What is the nursing students' perception about the ability of digital transformation in faculty of nursing?

\section{Subjects \& Methods \\ Research design:}

A descriptive correlational research design was utilized to fulfill the aim of this study.

\section{Setting:}

The study was conducted at faculty of nursing in both $\mathrm{A}=$ Sohag and $\mathrm{B}=$ South Valley Universities.

\section{Sample:}

A convenient sample of nursing faculty students of all academic years in both Sohag and South Valley Universities. Population size was 1011 at faculty of nursing South Valley University and 870 students at faculty of nursing Sohag University. Sample size was 267 and 279 students from South Valley and Sohag
Faculties of Nursing Universities respectively, calculated using OpenEpi, Version 3 software, open source calculator. The sample had been estimated with margin of error at $5 \%$ and confidence interval level at $95 \%$.

\section{Study tools}

An interviewing questioner cover three parts was used to collect data in this study. Tool developed by the researchers in Arabic language after reviewing the related literature, through using Google forms "the electronic form started by the aim of the study". It consists of the following parts in one electronic form which needs about 15 minutes to be completed:

Part 1: Personal data encompasses university, age and sex.

Part 2: assessment of digital transformation during COVID-19 this part designed to assess the students' perception of digital transformation during the quarantine period of COVID-19 pandemic. Responses were measured on five point's Likert scale five point's Likert scale as follows: strongly agree (5points), agree (4 points), neutral (3 points), disagree ( 2 points) and strongly disagree (1point). This part was grouped into 6 categories of 34 items as the following:

- Ability to learn 8 items.

- Ability to communicate 8 items.

- Technological / digital skills 3 items.

- Availability of resources 8 items.

- Platforms and apps used in broadcast of contents 4 items".

- Faculty members' performance 3 items.

Third part: the ability to compliance with digital transformation it designed to assess students' perception of the future ability to compliance with digital transformation, it follows the same responses as the previously mentioned tool. It includes 14 items.

Scoring system for this part: Student perception considered satisfactory at $50 \%$. Regarding assessment of digital transformation during COVID19 score 85 (of 170 the total score) considered satisfactory. While the ability to compliance with digital transformation scores 35 (of 70 the total score) are unsatisfactory.

\section{Methods}

This study ideation started at the beginning of April 2020 then reviewing literature, preparing the study proposal and designing the study tool was prepared from April to August 2020.

Validity was checked by three professors in nursing field, two of them are affiliated to Assiut University and one is affiliated to Cairo University.

Pilot study has been conducted on $10 \% \quad(188$ students) of participants. Reliability of the 
questionnaire was tested using Cronbach's Alpha test and turned out to be 0.969 . The pilot study data had been included in the total study sample "as no modifications were needed for the study tools"

Approval for data collection was conducted from the deans of designated settings.

Data was collected on September 2020 from the study sample.

Study tools electronic links were shared to participants through WhatsApp groups, with an introductory message that induct participants to fill in the questionnaire. Link closed to stop receiving responses when reached the estimated sample number.

\section{Data Collection:-}

A total of 267 and 279 students from South Valley and Sohag Faculties of Nursing Universities respectively participated in this study. They were selected through convenience sampling. The participants were invited through WhatsApp groups with information on the purpose of the study and the time would take to complete the questionnaire. The questionnaire was administered through a Google Form that was sent along with all the information and the invitation to participate through WhatsApp groups. The online questionnaire was designed in English and translated into Arabic. On the first page of the online questionnaire, students were informed about the background and objectives of the study. All the students' responses were gathered in an online spreadsheet to assess the digital transformation in nursing education as perceived by students of COVID-19. It took about 15 minutes to complete the questionnaire.

\section{Ethical considerations}

- Each student was informed about the aim of the study in the description of the questionnaire before starting. Students were informed that participation in the study is voluntary and that they had the right to withdraw from the study at any time before completing the questionnaire with no consequences, without giving any reason and that their responses would be held confidentially

- Study proposal had been approved from the Scientific Research Ethical Committee of the Faculty of Nursing Sohag University on September 10, 2020; a statement clarifies that collected data will not be used except in research purposes have been included in the electronic questionnaire. Anonymity of the collected data has been ensured to protect participants' collected data confidentiality. And Electronic submission of the filled in questionnaire from the study sample participants considered approval from them to participate in the study.

\section{Statistical analysis}

Statistical analyses were performed with IBM SPSS 26.0 software. The data were tested for normality using the Anderson-Darling test and for homogeneity variances. Categorical variables were described by number and percent ( $\mathrm{N} \%$ ), where continuous variables described by mean and standard deviation (Mean, SD). Chi-square test used to compare between categorical variables where comparisons between continuous variables by t-test. A two-tailed $\mathrm{P}>0.05$ was considered statistically non-significant, $\mathrm{p}$ $<0.05$ significant, $\mathrm{P}<0.01$ moderate significant while $\mathrm{P}<0.001$ highly significant. 


\section{Results}

Table (1): Distribution of study sample personal characteristics at Faculties of Nursing of South of Valley and Sohag Universities

\begin{tabular}{|c|c|c|c|c|c|c|}
\hline \multirow[t]{2}{*}{ Personal characteristics } & \multicolumn{2}{|c|}{$\begin{array}{c}\text { South of Valley } \\
(\text { No. =267) }\end{array}$} & \multicolumn{2}{|c|}{$\begin{array}{c}\text { Sohag } \\
(\text { No. = 279) }\end{array}$} & \multirow[t]{2}{*}{$\mathbf{X}^{2}$} & \multirow[t]{2}{*}{ P-value } \\
\hline & No. & $\%$ & No. & $\%$ & & \\
\hline \multicolumn{7}{|l|}{ Sex } \\
\hline - Male & 121 & 45.3 & 128 & 45.9 & \multirow[t]{2}{*}{0.017} & \multirow[t]{2}{*}{0.896} \\
\hline - Female & 146 & 54.7 & 151 & 54.1 & & \\
\hline Mean \pm SD of age & \multicolumn{2}{|c|}{$20.57 \pm 1.241$} & \multicolumn{2}{|c|}{$20.25 \pm 1.699$} & $F=6.067$ & $0.014 *$ \\
\hline
\end{tabular}

Table (2): Distribution of the study sample regarding ability to learn during the quarantine period of COVID-19 pandemic

\begin{tabular}{|c|c|c|c|c|c|c|c|c|}
\hline \multirow[t]{2}{*}{ Items } & \multirow{2}{*}{ 㝵 } & $\begin{array}{l}\text { Strongly } \\
\text { disagree }\end{array}$ & Disagree & Neutral & Agree & $\begin{array}{l}\text { Strongly } \\
\text { agree }\end{array}$ & \multirow[t]{2}{*}{$\mathbf{X}^{2}$} & \multirow{2}{*}{$\begin{array}{c}\mathbf{P} \\
\text { value }\end{array}$} \\
\hline & & $\%$ & $\%$ & $\%$ & $\%$ & $\%$ & & \\
\hline \multirow{2}{*}{$\begin{array}{l}\text { There was better } \\
\text { understanding of scientific } \\
\text { material. }\end{array}$} & A & 35.2 & 21.7 & 29.6 & 8.2 & 5.2 & \multirow{2}{*}{2.524} & \multirow{2}{*}{0.640} \\
\hline & $\mathrm{B}$ & 36.6 & 26.2 & 26.5 & 6.8 & 3.9 & & \\
\hline \multirow{2}{*}{$\begin{array}{l}\text { Safety is maintained during } \\
\text { the current COVID-19 } \\
\text { pandemic, without disrupted } \\
\text { study. }\end{array}$} & A & 21.7 & 19.1 & 27.3 & 24.0 & 7.9 & \multirow{2}{*}{6.682} & \multirow{2}{*}{0.154} \\
\hline & $\mathrm{B}$ & 21.1 & 21.5 & 33.3 & 15.8 & 8.2 & & \\
\hline \multirow{2}{*}{$\begin{array}{l}\text { The speed of learning suits } \\
\text { differences in students' } \\
\text { abilities. }\end{array}$} & $\mathrm{A}$ & 32.6 & 28.5 & 19.9 & 13.1 & 6.0 & \multirow{2}{*}{6.141} & \multirow{2}{*}{0.189} \\
\hline & $\mathrm{B}$ & 25.8 & 36.9 & 18.6 & 14.3 & 4.3 & & \\
\hline \multirow{2}{*}{$\begin{array}{l}\text { Following up the scientific } \\
\text { content introduced during the } \\
\text { pandemic raised experiences } \\
\text { and skills. }\end{array}$} & A & 25.1 & 30.0 & 24.0 & 13.9 & 7.1 & \multirow{2}{*}{3.485} & \multirow{2}{*}{0.480} \\
\hline & $\mathrm{B}$ & 26.5 & 26.5 & 28.0 & 14.7 & 4.3 & & \\
\hline \multirow{2}{*}{$\begin{array}{l}\text { Learning via electronic } \\
\text { platforms in nursing subjects } \\
\text { is better than the traditional } \\
\text { academic learning during the } \\
\text { pandemic. }\end{array}$} & A & 39.0 & 27.0 & 10.5 & 15.0 & 8.6 & \multirow[t]{2}{*}{5.765} & \multirow[t]{2}{*}{0.217} \\
\hline & $\mathrm{B}$ & 41.2 & 31.9 & 9.0 & 13.6 & 4.3 & & \\
\hline \multirow{2}{*}{$\begin{array}{l}\text { Learning via electronic } \\
\text { platforms in supplementary } \\
\text { subjects is better than the } \\
\text { traditional academic learning } \\
\text { during the pandemic. }\end{array}$} & A & 32.2 & 24.0 & 15.0 & 19.9 & 9.0 & \multirow[t]{2}{*}{2.144} & \multirow[t]{2}{*}{0.709} \\
\hline & B & 30.5 & 26.9 & 17.6 & 18.3 & 6.8 & & \\
\hline \multirow{2}{*}{$\begin{array}{l}\text { Lectures followed daily on } \\
\text { the electronic platforms }\end{array}$} & $\mathrm{A}$ & 19.5 & 19.1 & 33.7 & 23.2 & 4.5 & \multirow{2}{*}{4.972} & \multirow{2}{*}{0.290} \\
\hline & $\mathrm{B}$ & 20.8 & 24.4 & 30.1 & 18.3 & 6.5 & & \\
\hline \multicolumn{9}{|c|}{$\begin{array}{l}P>0.05 \text { non-significant } \\
* * * P<0.001 \text { highly significant } \\
\text { A (Faculty of Nursing }- \text { South of Valley University, No. }=267 \text { students })\end{array}$} \\
\hline
\end{tabular}


Table (3): Distribution of the study sample regarding the ability to communicate during the quarantine period of COVID-19 pandemic

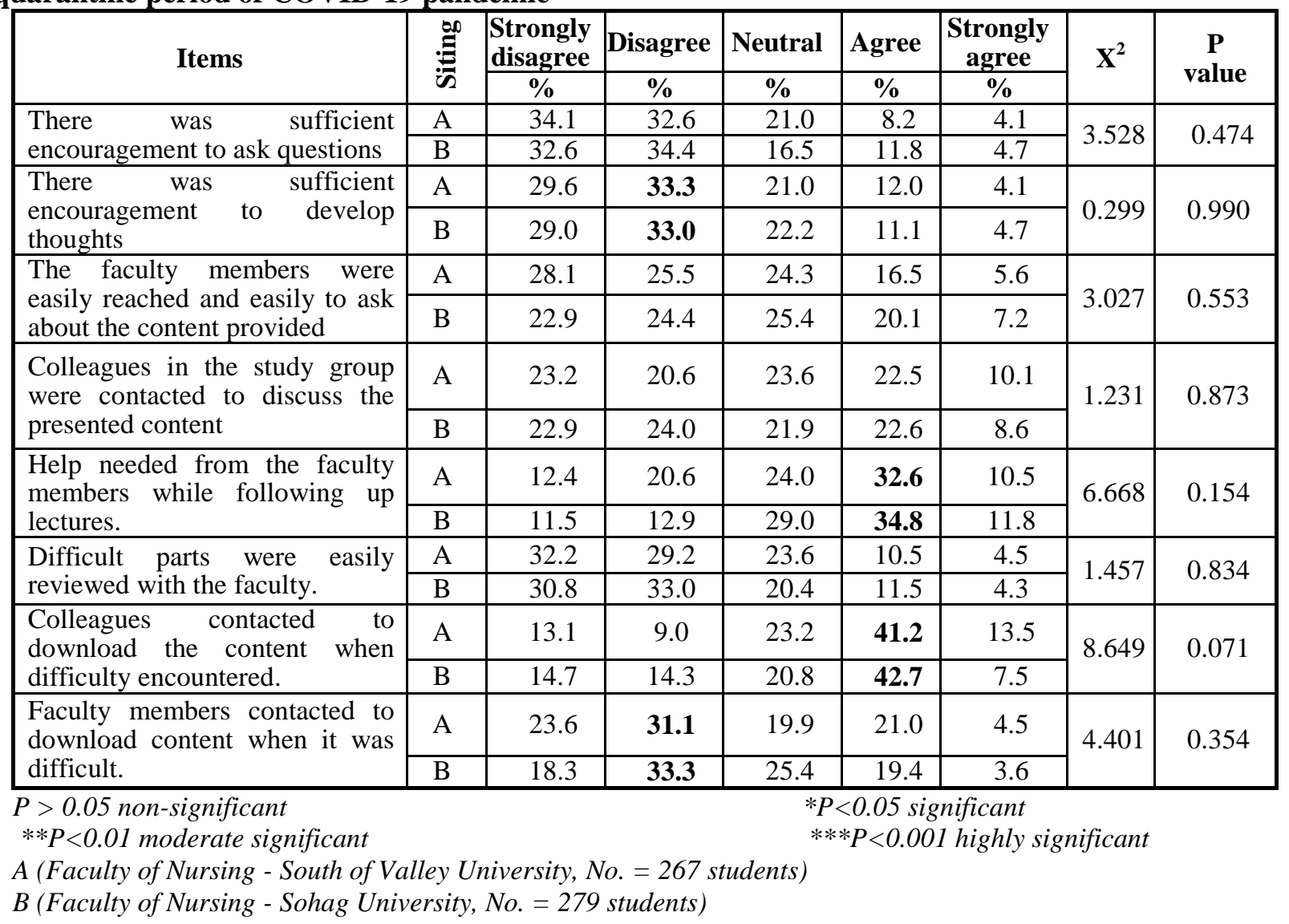

Table (4): Distribution of the study sample regarding technological / digital skills during the quarantine period of COVID-19 pandemic

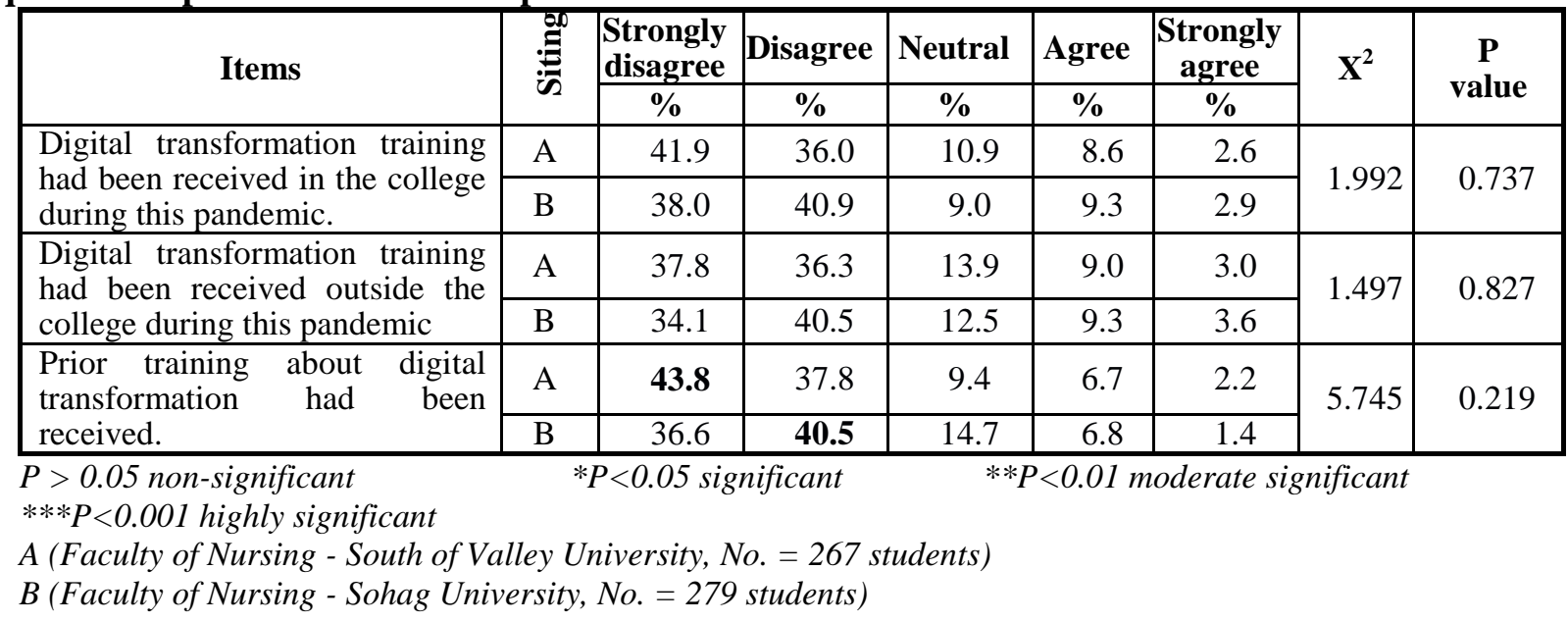


Table (5): Distribution of the study sample regarding the availability of capabilities during the quarantine period of COVID-19 pandemic

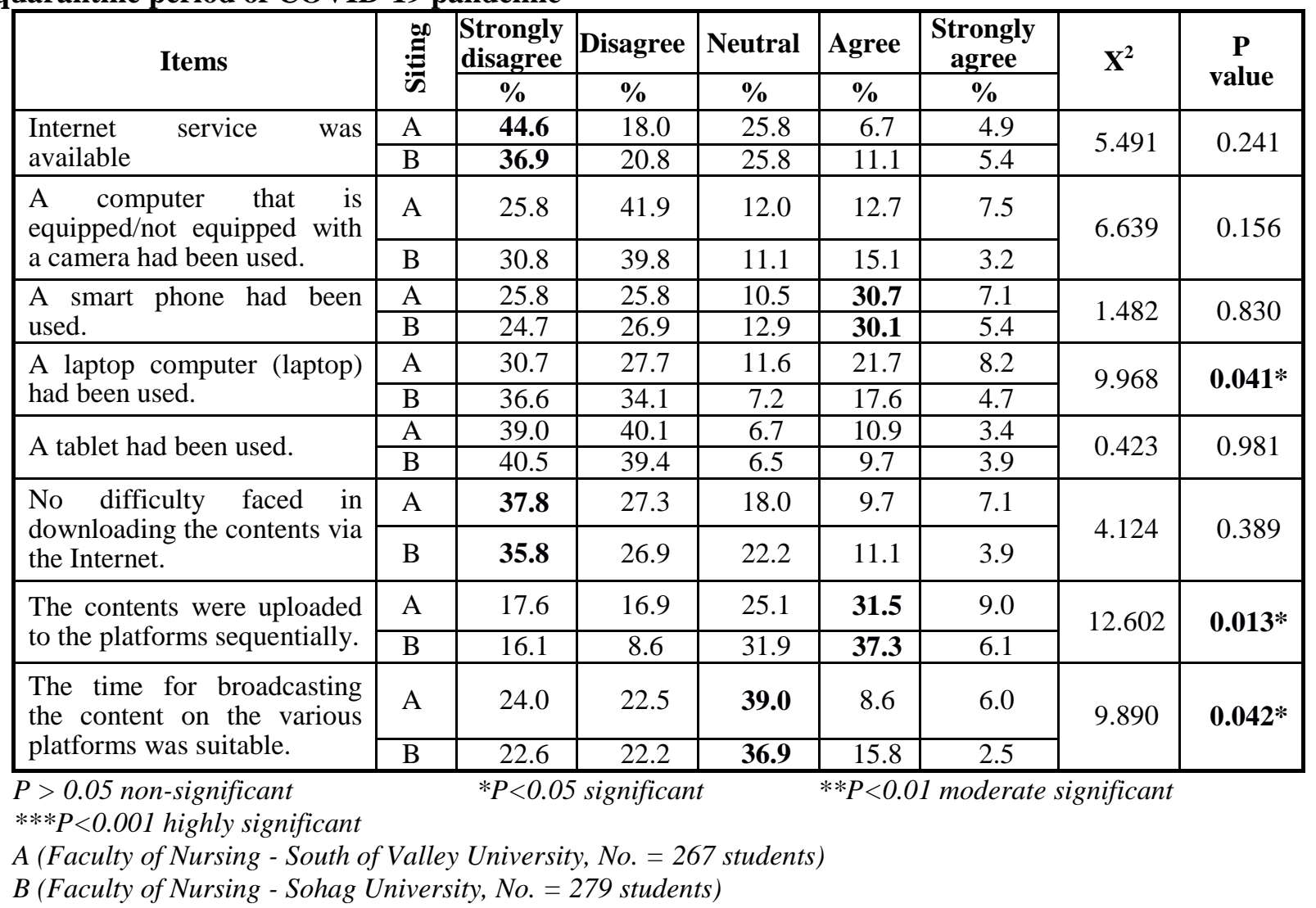

Table (6): Distribution of the study sample regarding platforms and apps used in broadcast of contents during the quarantine period of COVID-19 pandemic

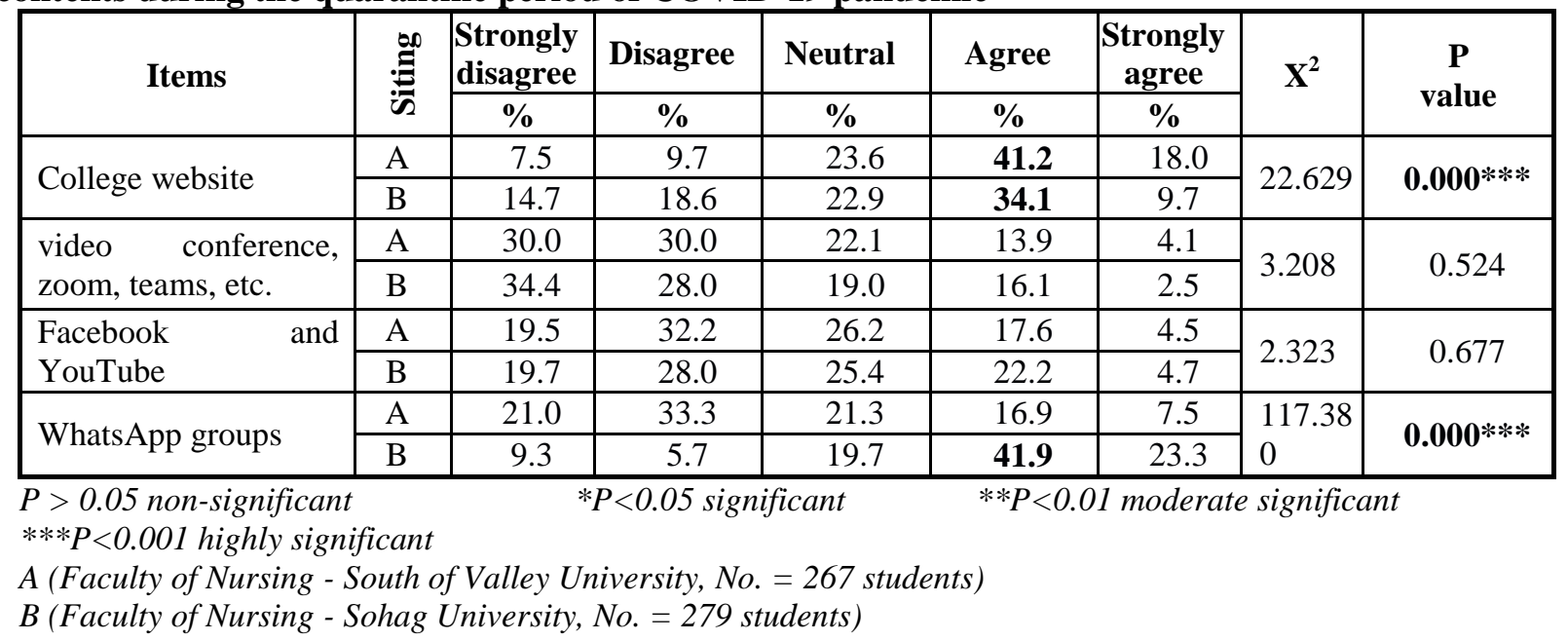


Table (7): Distribution of the study sample regarding faculty members' performance during the quarantine period of COVID-19 pandemic

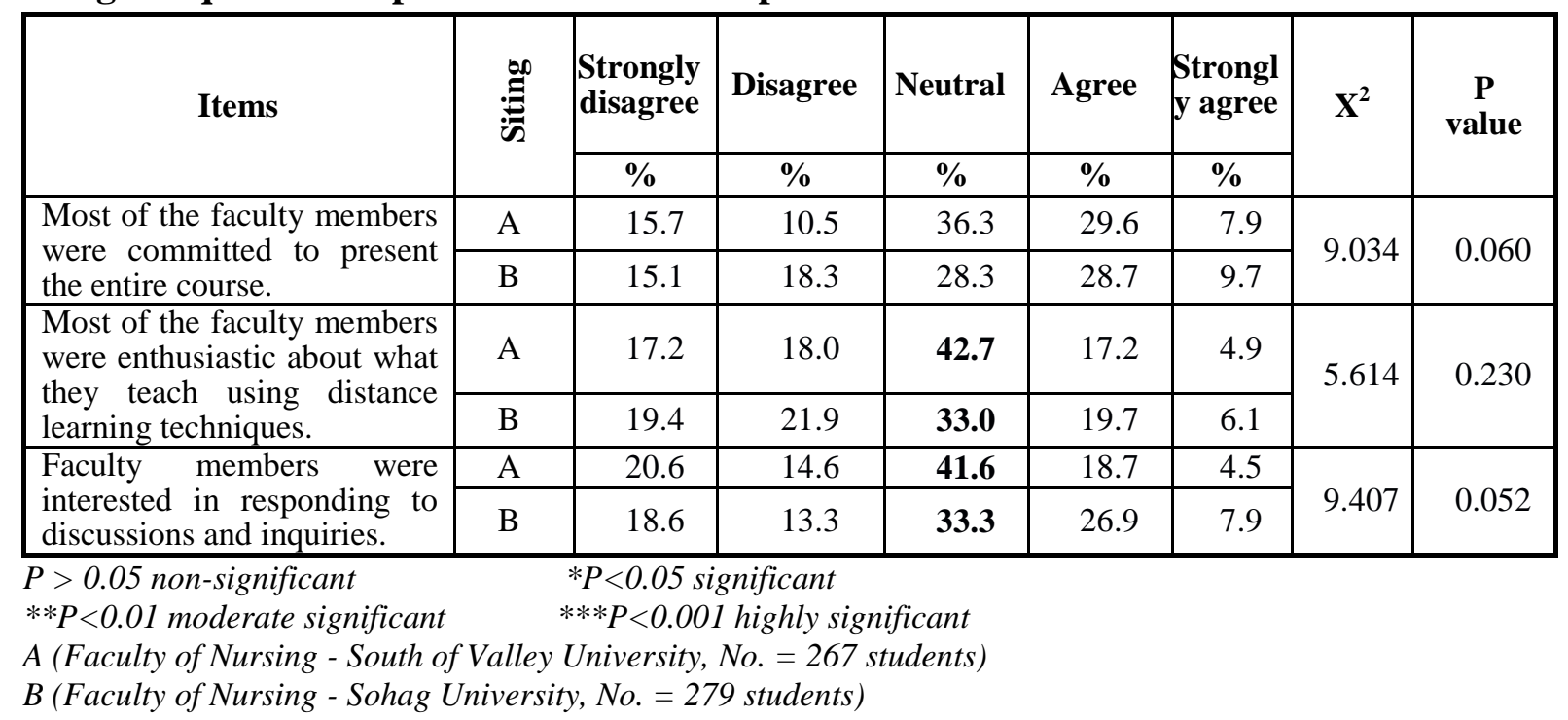

Table (8): Distribution of the study sample ability of digital transformation

\begin{tabular}{|c|c|c|c|c|c|c|c|c|}
\hline Items & : & \begin{tabular}{|c|}
$\begin{array}{l}\text { Strongly } \\
\text { disagree }\end{array}$ \\
$\%$
\end{tabular} & \begin{tabular}{|c|} 
Disagree \\
$\%$
\end{tabular} & \begin{tabular}{|c|} 
Neutral \\
$\%$
\end{tabular} & \begin{tabular}{c|} 
Agree \\
$\%$
\end{tabular} & \begin{tabular}{|c|}
$\begin{array}{c}\text { Strongly } \\
\text { agree }\end{array}$ \\
$\%$
\end{tabular} & $\mathbf{X}^{2}$ & $\begin{array}{c}\text { P- } \\
\text { value }\end{array}$ \\
\hline \multirow{2}{*}{$\begin{array}{l}\text { Nursing colleges' students are able to } \\
\text { meet digital transformation in } \\
\text { learning. }\end{array}$} & A & 33.7 & 21.0 & 24.0 & 13.9 & 7.5 & \multirow{2}{*}{1.119} & \multirow{2}{*}{0.891} \\
\hline & B & 34.1 & 22.2 & 25.8 & 11.8 & 6.1 & & \\
\hline \multirow{2}{*}{$\begin{array}{l}\text { The College has the ability to } \\
\text { transform to suit the requirements of } \\
\text { digital transformation. }\end{array}$} & A & 27.0 & 17.6 & 35.6 & 12.7 & 7.1 & \multirow{2}{*}{11.964} & \multirow{2}{*}{ 0.018* } \\
\hline & B & 27.6 & 26.2 & 28.7 & 14.7 & 2.9 & & \\
\hline \multirow{2}{*}{$\begin{array}{l}\text { The technological / digital skills of } \\
\text { most faculty members enable for } \\
\text { digital transformation. }\end{array}$} & A & 26.2 & 16.5 & 36.7 & 15.7 & 4.9 & \multirow{2}{*}{5.224} & \multirow{2}{*}{0.265} \\
\hline & $\mathrm{B}$ & 25.1 & 24.0 & 33.7 & 12.5 & 4.7 & & \\
\hline \multirow{2}{*}{$\begin{array}{l}\text { The capabilities available in the } \\
\text { college and university are appropriate } \\
\text { for digital transformation. }\end{array}$} & A & 31.8 & 20.6 & 30.7 & 12.4 & 4.5 & \multirow{2}{*}{4.144} & \multirow{2}{*}{0.387} \\
\hline & $\mathrm{B}$ & 31.5 & 27.2 & 27.6 & 9.3 & 4.3 & & \\
\hline \multirow{2}{*}{$\begin{array}{l}\text { I have advanced technological skills } \\
\text { in using techniques and methods of } \\
\text { electronic learning. }\end{array}$} & A & 24.7 & 19.5 & 34.8 & 13.5 & 7.5 & \multirow{2}{*}{1.708} & \multirow[t]{2}{*}{0.789} \\
\hline & $\mathrm{B}$ & 21.5 & 20.4 & 35.1 & 16.5 & 6.5 & & \\
\hline \multirow{2}{*}{$\begin{array}{l}\text { I support distance education through } \\
\text { platforms in my nursing studies. }\end{array}$} & A & 35.6 & 25.5 & 22.8 & 7.9 & 8.2 & \multirow{2}{*}{9.140} & \multirow{2}{*}{0.058} \\
\hline & $\mathrm{B}$ & 41.2 & 26.9 & 14.7 & 11.5 & 5.7 & & \\
\hline \multirow{2}{*}{$\begin{array}{l}\text { Technologies in nursing education } \\
\text { help to face crises such as the current } \\
\text { COVID-19 pandemic. }\end{array}$} & $\mathrm{A}$ & 25.5 & 20.2 & 24.0 & 20.2 & 10.1 & \multirow{2}{*}{1.435} & \multirow{2}{*}{0.838} \\
\hline & B & 23.3 & 22.6 & 21.9 & 22.9 & 9.3 & & \\
\hline \multirow{2}{*}{$\begin{array}{l}\text { Learning via electronic platforms is } \\
\text { appropriate for nursing subjects' } \\
\text { education in normal circumstances. }\end{array}$} & A & 40.1 & 25.8 & 19.5 & 9.4 & 5.2 & \multirow[t]{2}{*}{1.974} & \multirow[t]{2}{*}{0.741} \\
\hline & $\mathrm{B}$ & 38.4 & 30.5 & 16.5 & 10.0 & 4.7 & & \\
\hline \multirow{2}{*}{$\begin{array}{l}\text { The most effective education in } \\
\text { nursing is face to face in the } \\
\text { classroom. }\end{array}$} & $\mathrm{A}$ & 11.6 & 5.6 & 15.4 & 19.1 & 48.3 & \multirow{2}{*}{3.505} & \multirow{2}{*}{0.477} \\
\hline & B & 7.9 & 6.8 & 13.6 & 22.9 & 48.7 & & \\
\hline \multirow{2}{*}{$\begin{array}{l}\text { College website is most effective in } \\
\text { education. }\end{array}$} & $\mathrm{A}$ & 15.0 & 9.4 & 31.1 & 31.5 & 13.1 & \multirow{2}{*}{11.369} & 0023* \\
\hline & $\mathrm{B}$ & 15.8 & 19.0 & 28.3 & 26.9 & 10.0 & & 0.025 \\
\hline Facebook, YouTube etc., are the most & $\mathrm{A}$ & 19.1 & 18.0 & 30.7 & 24.3 & 7.9 & 0 & 0741 \\
\hline effective in education. & $\mathrm{B}$ & 15.8 & 21.1 & 30.5 & 23.3 & 9.3 & 910 & \\
\hline
\end{tabular}




\begin{tabular}{|c|c|c|c|c|c|c|c|c|}
\hline Items & $\stackrel{900}{E}$ & $\begin{array}{l}\begin{array}{l}\text { Strongly } \\
\text { disagree }\end{array} \\
\end{array}$ & Disagree & Neutral & Agree & $\begin{array}{c}\text { Strongly } \\
\text { agree }\end{array}$ & \multirow[t]{2}{*}{$X^{2}$} & \multirow{2}{*}{$\begin{array}{c}\text { P- } \\
\text { value }\end{array}$} \\
\hline & & $\%$ & $\%$ & $\%$ & $\%$ & $\%$ & & \\
\hline \multirow{2}{*}{$\begin{array}{l}\text { WhatsApp groups are the most } \\
\text { effective in education. }\end{array}$} & $\mathrm{A}$ & 22.5 & 22.5 & 26.2 & 18.4 & 10.5 & \multirow[b]{2}{*}{19.137} & \multirow{2}{*}{$\begin{array}{c}\mathbf{0 . 0 0 1 *} \\
* *\end{array}$} \\
\hline & $\mathrm{B}$ & 17.9 & 18.1 & 28.4 & 23.4 & 12.1 & & \\
\hline \multirow{2}{*}{$\begin{array}{l}\text { Videos or recorded materials are the } \\
\text { most effective in education. }\end{array}$} & A & 19.1 & 7.5 & 23.6 & 37.8 & 12.0 & \multirow{2}{*}{8.309} & \multirow{2}{*}{0.081} \\
\hline & $\mathrm{B}$ & 12.2 & 12.9 & 24.4 & 37.3 & 13.3 & & \\
\hline \multirow{2}{*}{$\begin{array}{l}\text { Video conference or zoom are the } \\
\text { most effective in education. }\end{array}$} & A & 16.9 & 11.2 & 28.1 & 30.3 & 13.5 & \multirow{2}{*}{2.793} & \multirow{2}{*}{0.593} \\
\hline & $\mathrm{B}$ & 15.8 & 12.5 & 23.7 & 30.5 & 17.6 & & \\
\hline
\end{tabular}

Table (9): Relation between students' satisfaction regarding learning experience during the quarantine period of COVID-19 pandemic in relation to digital transformation ability of faculties of nursing

\begin{tabular}{|c|c|c|c|c|c|c|c|c|c|}
\hline \multirow{3}{*}{\multicolumn{2}{|c|}{ University }} & \multicolumn{4}{|c|}{ Digital transformation ability } & \multirow{2}{*}{\multicolumn{2}{|c|}{$\begin{array}{c}\text { Total } \\
\text { satisfaction }\end{array}$}} & \multirow{3}{*}{$X^{2}$} & \multirow{3}{*}{ P-value } \\
\hline & & \multicolumn{2}{|c|}{ Not able } & \multicolumn{2}{|c|}{ Able } & & & & \\
\hline & & N. & $\%$ & N. & $\%$ & N. & $\%$ & & \\
\hline \multirow{3}{*}{$\begin{array}{c}\text { Faculty of } \\
\text { Nursing South } \\
\text { Valley } \\
\text { University } \\
\text { No. }=267\end{array}$} & Un-satisfaction & 64 & 24.0 & 6 & 2.2 & 70 & 26.2 & \multirow[t]{6}{*}{111.84} & \multirow[t]{6}{*}{$0.000 * * *$} \\
\hline & Satisfaction & 39 & 14.6 & 185 & 59.2 & 197 & $\mathbf{7 3 . 8}$ & & \\
\hline & Total ability & 103 & 38.6 & 191 & 61.4 & & & & \\
\hline \multirow{3}{*}{$\begin{array}{c}\text { Faculty of } \\
\text { Nursing Sohag } \\
\text { University } \\
\text { No. }=\mathbf{2 7 9}\end{array}$} & Un-satisfaction & 58 & 20.8 & 5 & 1.8 & 63 & 22.6 & & \\
\hline & Satisfaction & 49 & 17.6 & 167 & 59.9 & 216 & $\mathbf{7 7 . 4}$ & & \\
\hline & Total ability & 107 & 38.4 & 172 & 61.6 & & & & \\
\hline
\end{tabular}

Table (1): Shows that, the highest percentage $54.7 \%$ and $54.1 \%$ of the study sample were females with no statistically significant difference between both faculties of nursing in South Valley and Sohag Universities $(p$-value $=0.896)$, and also there was statistically significant difference between both groups regarding to mean age ( $\mathrm{p}$-value $=0.014)$.

Table (2): Demonstrates that the highest percentage was for study sample strongly disagree that "There was better understanding of scientific material" $35.2 \%$ and $36.6 \%$; "Learning via electronic platforms in nursing subjects is better than the traditional academic learning during the pandemic" $39.0 \%$ and $41.2 \%$ in addition "Learning via electronic platforms in supplementary subjects is better than the traditional academic learning during the pandemic" $32.2 \%$ and $30.5 \%$ at both faculties A and B respectively.

Regarding neutral responses the highest percentage was for "Safety is maintained during the current COVID-19 pandemic, without disrupted study" $27.3 \%$ and $33.3 \%$ moreover "Lectures followed daily on the electronic platforms" $33.7 \%$ and $30.1 \%$ at faculties A and B respectively. No statistically significant difference was found $\mathrm{P}>0.05$.

Table (3): Declares that highest percentage was for study sample disagree that "There was sufficient encouragement to develop thoughts" $33.3 \%$ and $33.0 \%$; and "Faculty members contacted to download content when it was difficult." $31.3 \%$ and $33.3 \%$ at faculties A and B respectively. While the highest percentage of the study sample was agree that "Help needed from the faculty members while following up lectures" $32.6 \%$ and $34.8 \%$; and "Colleagues contacted to download the content when difficulty encountered" $31.1 \%$ and $33.3 \%$ at both faculties A and $\mathrm{B}$ respectively. No statistically significant difference found $\mathrm{P}>0.05$.

Table (4): Shows that highest percentage of the study sample $43.8 \%$ strongly disagree and $40.5 \%$ disagree that "Prior training about digital transformation had been received" at both faculties A and B respectively. No statistically significant difference as $\mathrm{P}>0.05$.

Table (5): Depicts that highest percentage was for study sample strongly disagree that "Internet service was available" $44.6 \%$ and $36.9 \%$; "No difficulty faced in downloading the contents via the Internet" 
$37.8 \%$ and $35.8 \%$; while they agree that " $\mathrm{A}$ smart phone had been used" $30.7 \%$ and $30.1 \%$ at faculties A and $\mathrm{B}$ respectively. No statistically significant difference as $\mathrm{P}>0.05$.

On the other hand the highest percentages were neutral for "The time for broadcasting the content on the various platforms was suitable" $39.0 \%$ and $36.9 \%$; and agree that "The contents were uploaded to the platforms sequentially" $31.5 \%$ and $37.3 \%$ at both A and B faculties respectively. There was statistical significant difference $\mathrm{P}<0.05$.

Table (6): Displays that agreement was $41.9 \%$ for Faculty of Sohag highest percentage, which used WhatsApp groups, while both faculties used college website $41.2 \%$ and $34.1 \%$ respectively. There was highly statistical significant difference $\mathrm{P}<0.001$.

Table (7): Denotes that the highest percentage was for study sample neutral response that "Most of the faculty members were enthusiastic about what they teach using distance learning techniques" $42.7 \%$ and $33.0 \%$; and "Faculty members were interested in responding to discussions and inquiries" $41.6 \%$ and $33.3 \%$ at both $\mathrm{A}$ and $\mathrm{B}$ faculties respectively. No statistically significant difference as $\mathrm{P}>0.05$.

Table (8): Demonstrates that the highest percentage was for study sample neutral response that "The College has the ability to transform to suit the requirements of digital transformation" $35.6 \%$ and $28.7 \%$ at faculties of nursing $\mathrm{A}$ and $\mathrm{B}$ respectively with statistically significant difference $\mathrm{P}<0.05$. In addition neutral response highest percentage was for "WhatsApp groups are the most effective in education" $26.2 \%$ and $28.4 \%$ at both faculties respectively there was highly statistically significant difference $\mathrm{P}<0.001$.

Table (9): Shows that the highest percentage 59.2\% and $59.9 \%$ of the study sample who are satisfied with the experience of distance learning during quarantine period of COVID-19 pandemic they perceived that the faculties of nursing are able to be digitally transformed in both nursing faculties of South Valley and Sohag universities respectively. There was highly statistical significant difference $\mathrm{P}<0.001$.

\section{Discussion}

COVID-19 has caused education disruptions and extensive closure of the educational institutions all over the world, causing most countries to think about alternative ways of providing education to ensure the continuity of learning UNESCO $(\mathbf{2 0 2 0}$ a). To achieve this continuity, most countries moved to online learning using online platforms and e-learning, which set off an unplanned and rapid shift in the education sector, that opened the door for several opportunities, highlighted existing and new disparities and gave rise to several challenges UNESCO (2020 b).

At the present study the total number of students participates in the study were five hundred and forty six students (two hundred and sixty seven from south valley university while two hundred and seventy nine from Sohag University). Just more than half of the participants were females in both universities and the mean age of the study participants were around age of twenty.

Owing to understanding of scientific material toughed through distant learning, current study revealed that about two thirds of the students in both faculties reported that they strongly disagree that distant learning through platform helps them in understanding the scientific material; distance learning helped me learn at the speed that suits me and according to my abilities and also that learning via electronic platforms in nursing is better than the traditional learning; with no statistical significance difference this reflect disability of students to learn through electronic methods in the two faculties during the quarantine period of the pandemic.

This come in the same line with study done by Abdulghani, et al., (2020), to assess the association of COVID-19 pandemic with undergraduate medical students' perceived stress and coping reported that highest percentage was nearly to half of medical students who enrolled in the study responded as "neutral" about "online learning content is difficult to understand". In contrast Ali, et al., (2016) study the attitude of nursing students towards e- learning found $86 \%$ of students said that their understanding of subject is enhanced and they can achieve better results as narrated by about three quarter, additionally overall more than fifty percent of nursing students included on the study have very strong perceptions for the usefulness of e-learning while only $40 \%$ are either neutral or disagree to some extent towards uses of e-learning over traditional learning.

In relation to ability to communicate with staff members, the present study illustrate that about two thirds of students responded with disagree that there was sufficient encouragement during the electronic broadcast to ask questions; develop thoughts and the difficult parts of the remote content were easily reviewed with faculty; in addition no statistically significant difference found between the results of two faculties. This agree with study carried by Amir, et al., (2020) who reported that in his study more students felt lower learning satisfaction and more difficult communication either with instructors or with peer students in doing distance learning. Moreover also the study conducted by Abbasi, et al., (2020) reported that $84 \%$ of the students rated that e- 
teaching cause limited student-teacher communication and interaction.

Concerning receiving enough technological/digital skills previously to quarantine period of Covid-19 pandemic, current study results stated that majority of students respond with disagree, this may be due to lack of serious endeavors towards digital transformation before the outbreak of COVID-19 both from the students and universities. This agree with Adams, et al., (2018) study findings which suggests the importance of making students aware of the technology in e-learning, and the availability of technological resources.

Regarding the availability of resources of e-learning during the Covid-19 pandemic, the results of current study revealed that most of students were disagree in their responses, with statistical significant difference regards Sohag and South of Valley Faculties of Nursing results in using students' for computer, laptop computer (laptop) and tablet. In addition the same response for internet service is available, uploading contents sequentially and the time for broadcasting the content was suitable. This also come in line with the study done by Amir, et al., (2020) reported that the barriers associated with infrastructure were obviously also encountered by the students complaining about unstable internet connection and extra financial burden for internet quota. On the other hand Abdulghani, (2020) who reported that provision of sufficient material is very crucial, but this remained a challenge, as the pandemic was not expected, and the preparedness of the faculty was not achieved by many medical schools.

Owing to platforms and apps used in broadcast of contents the results of present study illustrate that the about two thirds of the students in faculty " $A$ " agrees that college website is the mostly used. In the other hand more than fifty percent of faculty " $\mathrm{B}$ " agrees that WhatsApp groups are the most frequently used. Highly statistically significant differences between these two variables were found. This reverses to the results of Clement. (2020) who mention that students preferred social media sites (Facebook and WhatsApp) for communication, which were not officially adopted by universities for e-learning, as digital natives who are techno-savvy enjoy the use of Web 2.0 applications with good user-friendliness and swift communication. As well as Khoza \& Biyela, (2019) share the same results that social media sites Plays the major role in digital mitigation to Achieve e-learning in current digital age. This were due to most students have access to social media sites because of free data which helps student to communicate learning also bundle access provided by network service providers.

Regarding Satisfaction of students with faculty member's performance during Covid-19 pandemic, current study results explore that no statistical significant difference. The highest percentage of the study sample responded as agree that "Most of the faculty members were committed to present the entire course". Regards South of Valley and Sohag Faculties of Nursing results related to "Faculty members were interested in responding to discussions and inquiries through the use of distance learning technologies during the pandemic" the highest percentage in faculty "A" agree while in faculty "B" the highest percentage were neutral in their responses.

This come in line with the study done by Gohiya, et al (2020), who tells that about $88 \%$ students felt that the staff members were successful in discussing the topics and that out of 56\% student who responded, reported that staff members were greatly successful in discussing the topic. As per feedback received, majority of students were satisfied with the staff knowledge of subject. Reporting that also the mode of learning is new but all the staff members were able to conduct classes comfortably.

Current study highlights that the highest percentage "less than two thirds" of the study sample who were satisfied with the experience of distance learning during quarantine period of COVID-19 pandemic perceived that the faculties of nursing are able to be digitally transformed in both nursing faculties of South Valley and Sohag universities respectively. High statistical significant difference was found. This answers the study questions

This come in line with the study done by Ali, et al., (2016), who shows that $85 \%$ of the nursing students enrolled in his study have strong intention (mean score 3.74) to adopt e-learning, and Sixty one percent plan to enroll and attend future e-learning courses and $69.5 \%$ students agree upon buying their personal computer. This could be due to the student high perception about importance of adopting digital transformation technology in nursing education especially in some crises, such as the current Corona virus crisis. Also in study done by Singh \& Min, (2017) on the efficacy of adapting digital lectures on gross anatomy, his study revealed that majority of the student's accepted and satisfied with e-learning. While come in contrast to study carried by Abbasi, et al., (2020) on medical and dental students who reported that student are not yet ready for using elearning and $77.4 \%$ students showed negative perception about e-learning, out of which $86 \%$ students felt e-learning has little impact on their 
learning and the majority of the students preferred face to face teaching over e-teaching.

\section{Conclusion}

Based on the findings of the present study, it can be concluded that the nursing students have satisfactory experience of digital transformation in learning during quarantine period of COVID-19 pandemic and they are perceive that faculties of nursing, staff members and students are able to digital transformation in the future, despite of limited availability of educational resources and difficulties faced students during that period in addition to lack of technological skills. There is highly statistical significant difference regarding learning experience during the pandemic in relation to digital transformation ability, so the results of each faculty cannot be considered a standard for other faculties of nursing.

\section{Recommendations:}

Based on the study findings, the following recommendations are suggested for effective digital transformation:

- Universities responsible and staff faculty members must take a corrective action in accord to findings.

- Provide technical support through qualified information technology employees.

- Equip the higher education institutions with essential infrastructure such as improved computer labs, studio for lectures broadcasting and platforms that help to overcome crisis such Covid-19 pandemic.

- Training of faculty staff members and students on the use of online modalities and technological / digital transformation skills.

- Governmental support for higher education students by providing tablets may be a choice help in digital transformation.

\section{References:}

- Abbasi, S. Ayoob, T. Malik, A \& Memon, S. (2020): Perceptions of students regarding $E$ learning during Covid-19 at a private medical college. Pakistan Journal of Medical Sciences, Vol. (36), N. COVID19-S4 (2020): COVID-19 Supplement Special Issue, Doi: available at https://doi.org/10.12669/pjms.36.COVID19-

S4.2766. Accessed on 20/11/2020.

- Abdulghani, HM. Sattar, K. Ahmad, T \& Akram, A. (2020): Association of COVID-19 Pandemic with undergraduate Medical Students' Perceived Stress and Coping. Journal of Psychology
Research and Behavior Management, Vol. (13), pages:871-881

- Adams, D. Sumintono, B. Mohamed, A. \& Noor, MN. (2018): E-learning readiness among students of diverse back groups in a leading Malaysian higher education institution, Malaysian Journal of Learning and Instruction, Vol. (15), No. (2), pages: 227-256.

- Ali, N. Jamil, B. Sethi, A. \& Ali. S. (2016): Attitude of nursing students towards e- learning. Advanced Health Professional Education, Vol. (2), No. (1), pages 24-29.

- Amir, L.R. Tanti, I. Maharani, D.A. Wimardhani, Y.S. Julia V, Sulijaya, B. \& Puspitawati. R., (2020): Student perspective of classroom and distance learning during COVID-19 pandemic in the undergraduate dental study program Universities Indonesia, BMC Medical Education Vol. (20), pages: 392 available at https://doi.org/10.1186/s12909-020-02312-0 Accessed on 10/10/2020.

- Armstrong-Mensah, E., Ramsey-White, K., Yankey, B. \& Self-Brown, S. (2020): COVID-19 and Distance Learning: Effects on Georgia State University School of Public Health Students, Frontiers in Public Health, Vol. (8), Article 576227, Doi: available at https://10.3389/fpubh.2020.576227. Accessed on 10/12/2020.

- Billings, D. (2018): What's the future for online teaching and learning in nursing education. By NLN nursing edge.

- Chick, R., Clifton, K., Peace, B., Propper, D., Hale, A., Alseidi, A. \& Vreeland, T., (2020): "Using Technology to Maintain the Education of Residents during the COVID-19 Pandemic." Journal of Surgical Education, Vol. (77), N. (4), Pages: 729-732. Doi: available at http://10.1016/j.jsurg.2020.03.018. Accessed on $15 / 1 / 2021$.

- Clement. J (2020): Most popular social networks worldwide as of January 2020, ranked by number of active users. Available at https: //www.statista.com/ statistics/272014/global-social-networks-ranked-bynumber-of-users. Accessed on 15/1/2021.

- Comi, S.G., Argentin, M., Gui, F., Origo \& Pagani, L., (2017): "Is it the Way They Use it? Teachers, ICT and Student Achievement." Economics of Education Review, Vol . (56), pages: 24-39.

- Gohiya, P., \& Gohiya, A., (2020): E -learning during Covid-19 Pandemic, research square, DOI: available at https://doi.org/10.21203/rs.3.rs29575/v1. Accessed on 3/1/2021 
- Jowsey, T., Foster, P., Cooper-Ioelu \& Jacobs, S., (2020): "Blended Learning via Distance in Preregistration Nursing Education: A Scoping Review." Nurse Education in Practice 44: 102775. available at Doi: http://10.1016/j.nepr.2020.102775 . Accessed on 20/12/2020.

- Khoza. S., \& Biyela. AT., (2020): Decolonizing technological pedagogical content knowledge of first year mathematics students. Education Inform Technology, vol. (1) pages: 1-15. Available at https://doi.org/10.1007/s10639-019-10084-4. Accessed on 30/11/2020.

- Kwary, DA., \& Fauzie, S., (2018): Students' achievement and opinions on the implementation of e-learning for phonetics and phonology. Education Pesqui, Vol. (44). Doi: available at http://10.1590/s1678-463420171017324. Accessed on 12/12/2020.

- Perrotta, C., (2020): Coronavirus quarantine could spark an online learning boom. Review available at https://theconversation.com/coronavirusquarantine- could-spark-an-online-learning-boom132180. Accessed on 1/11/2020.

- Singh, A., \& Min, AK. (2017): Digital lectures for learning gross anatomy: a study of their efficacy. Korean J Med Educ. Vol. (29), pages: 27-32. Available at doi: 10.3946/kjme.2017.50. Accessed on 30/9/2020.

- Song, Z., Wang, C., \& Bergmann, L. (2020): China's prefectural digital divide: Spatial analysis and multivariate determinants of ICT diffusion. International Journal of Information Management: The Journal for Information Professionals. June 2020, Available at https://doi.org/10.1016/j.ijinfomgt.2020.102072, Accessed on 20/8/2020.

- UNESCO (2020) a, COVID-19 education response: Virtual knowledge-sharing workshop on distance education programmers using radio and television, summary report available at: https://unesdoc.unesco.org/ark:/48223/pf000037357 6ng. Accessed on 27/5/2020.

- UNESCO (2020) b, issue note: Distance learning strategies in response to COVID-19 school closures available https://unesdoc unesco.org/ark:/48223/pf000037330 5. Accessed on 23/4/2020.

- Vial, G., (2019): Understanding digital transformation: A review and a research agenda, The Journal of Strategic Information Systems, Vol (28), N. (2), Pages: 118- 144.

- Zamira, H, D \& Linda, H. (2020): The impact of COVID-19 on higher education: A study of interaction among students' mental health, attitudes toward online learning, study skills, and changes in students' life. The paper available at: https://www.researchgate.net/publication/34159968 4, Accessed on 22/12/2020. 